\title{
Kendala-Kendala dalam Pembinaan Moral di Lembaga Pembinaan Khusus Anak (LPKA) Kelas II B Tanjung Pati
}

\author{
Riyan Ardinata, Rita Angraini \\ Prodi Pendidikan Pancasila dan Kewarganegaraan \\ FIS Universitas Negeri Padang \\ E-mail: riyanardinata05@gmail.com
}

\section{ABSTRAK}

Artikel ini bertujuan untuk mengetahui kendala-kendala dalam pelaksanaan pembinaan moral di LPKA Kelas II B Tanjung Pati. Jenis penelitian ini adalah penelitian deskriptif dengan pendekatan kualitatif. Dalam menentukan sampel penelitian, peneliti menggunakan teknik Purposeful sampling. Informan dalam penelitian ini adalah Kasi Pembinaan LPKA, staf pembinaan LPKA, Kasi Registrasi dan Klasifikasi LPKA. Teknik pengumpulan data yang digunakan dalam penelitian ini adalah observasi, wawancara dan studi dokumentasi. Teknik analisis data dalam penelitian yaitu pengumpulan data, reduksi data, penyajian data, penarikan kesimpulan dan verifikasi. Hasil penelitian ini menunjukan tidak berjalannya program pembinaan yang telah direncanakan akibat pandemi COVID-19, kekurangan tenaga ahli, dan keterbatasan fasilitas dalam melaksanakan pembinaan di masa Pandemi COVID-19.

Kata Kunci: pembinaan moral, Tanjung Pati, Covid-19

\section{ABSTRACT}

This article aims to determine the obstacles in the implementation of moral coaching in LPKA Class II B Tanjung Pati. This type of research is a descriptive study with a qualitative approach. In determining the research sample, researchers used purposive sampling technique. The informants in this study were the Head of LPKA Coaching, LPKA Coaching Staff, the Head of Registration and Classification of LPKA. The data collection techniques used in this research were observation, interview and documentation study. Data analysis techniques in research are data collection, data reduction, data presentation, drawing conclusions and verification. The results of this study indicate the failure of the coaching program that had been planned due to the COVID-19 pandemic, a shortage of experts, and limited facilities in carrying out coaching during the COVID-19 Pandemic.

Keywords: moral development, Tanjung Pati, Covid-19 


\section{PENDAHULUAN}

Lembaga

Pembinaan

Khusus Anak (LPKA) merupakan suatu lembaga untuk membina dan mendidik anak yang telah dijatuhi pidana penjara berdasarkan putusan pengadilan. LPKA merupakan perubahan nama yang sebelumnya bernama Lembaga Pemasyarakatan Anak. Perubahan tersebut dilakukan seiring dengan diberlakukannya Undang-Undang Nomor 11 Tahun 2012 Tentang Sistem Peradilan Pidana Anak (UU SPPA) menggantikan UndangUndang Nomor 3 Tahun 1997 tentang Pengadilan Anak (UU Pengadilan Anak). Alasan digantikannya UU Pengadilan Anak dengan UU SPPA karena UU Pengadilan Anak dianggap sudah tidak sesuai lagi dengan kebutuhan hukum dalam masyarakat dan belum secara menyeluruh memberikan perlindungan khusus kepada anak yang berhadapan dengan hukum (Yuliyanto \& Ernis, 2016: 1).

LPKA tidak hanya sebagai tempat untuk anak didik menjalani masa pidananya. LPKA mempunyai kewajiban untuk menyelenggarakan pendidikan, pelatihan keterampilan, pembinaan dan pemenuhan hak-hak lain dari anak sesuai dengan peraturan perundang-undangan yang berlaku (Eriza, 2018: 2). Pemberian pembinaan kepada anak didik berbeda dengan pembinaan narapidana dewasa karena anak masih memiliki kesempatan berkembang dan memiliki masa depan yang lebih panjang. Anak juga dapat menjadi potensi dan modal bagi pembangunan bangsa. Oleh karena itu, pemberian pembinaan dan bimbingan kepada narapidana diharapkan dapat mengubah mental dan kepribadian mejadi lebih baik sesuai dengan norma yang berlaku pada masyarakat.

Salah satu LPKA di Indonesia terdapat di Provinsi Sumatera Barat yaitu Lembaga Pembinaan Khusus Anak Kelas IIB Tanjung Pati yang bertempat di Tanjung Pati, Kabupaten Lima Puluh Kota. LPKA ini merupakan lembaga berada di bawah naungan Kementerian Hukum dan Hak Asasi Manusia (Kemkumham) sebagai pelaksana dalam pembinaan anak. LPKA Tanjung Pati memiliki daya tampung 163 orang dengan pembagian dua blok hunian laki-laki dan perempuan. LPKA ini masih digabungkan dengan Lembaga Pemasyarakatan Perempuan (LPP). Narapidana perempuan yang berada di LPKA Kelas II B Sumatera Barat merupakan narapidana yang dititipkan dari LPP Kelas IIB Padang. Hal ini dikarenakan pembangun LPP masih belum 
maksimal karena baru dibangun pada tahun 2018.

LPKA Kelas II B Sumbar memiliki dua bentuk pembinaan untuk anak didik yaitu pembinaan kepribadian dan kemandirian. Berdasarkan penelitian terdahulu, Fitesa (2016) dalam skripsinya yang berjudul "Peran Petugas Lembaga Pembinaan Khusus Anak (LPKA) Kelas IIB Dalam Memberikan Pembinaan Terhadap Anak Didik Pemasyarakatan (Studi di LPKA Kelas IIB Provinsi Sumatera Barat)" yang menyatakan bahwa pembinaan kepribadian terdiri dari pembinaan berupa pendidikan agama dan budi pekerti, pendidikan formal dan kesadaran hukum. Sedangkan pembinaan kemandirian terdiri dari kegiatan pembinaan fisik, senam, pembinaan keterampilan dan pembinaan kesenian (Fitesa, 2016).

Pembinaan kepribadian memiliki peran penting dalam membina moral anak didik pemasyarakatan. Pembinaan kepribadian adalah pembinaan mental dan watak anak agar menjadi manusia seutuhnya, bertakwa dan bertanggung jawab pada diri sendiri (Keputusan Menteri Hukum dan Hak Asasi Manusia RI Nomor M.HH03.OT.02.02. 2014). Pembinaan kepribadian terdiri dari kegiatan pembinaan kerohanian, kesadaran hukum, jasmani, kesadaran berbangsa dan bernegara. Moral anak akan dibina melalui empat program pembinaan tersebut.

Namun, terdapat berbagai kendala dalam pelaksanaan pembinaan di LPKA Kelas IIB Tanjung Pati. Berdasarkan observasi penulis kendala tersebut adalah kurang berjalannya program pembinaan di LPKA tersebut akibat pandemi Covid-19, kurangnya tenaga ahli dalam pembinaan moral di LPKA, serta kurangnya fasilitas dalam pembinaan pada masa pandemi Covid-19.

Penelitian ini memfokuskan bagaimana kendala LPKA Kelas IIB dalam melakukan pembinaan moral melalui pembinaan kepribadian. Usaha pembinaan moral pada generasi muda sangat penting karena generasi muda merupakan bagian dari masyarakat yang kelak akan menjadi penerus pembangunan bangsa (Nurmalisa \& Adha, 2016: 65).

\section{METODE PENELITIAN}

Jenis penelitian ini adalah kualitatif deskriptif yang tujuan untuk menjelaskan kendalakendala dalam pembinaan moral di Lembaga Pembinaan Khusus Anak (LPKA) Kelas II B Tanjung Pati (Sudaryono. 2018). Informan dalam penelitian ini adalah kepala seksi pembinaan LPKA, kepala seksi 
registrasi dan klasifikasi, petugas LPKA. Teknik sampling yang digunakan pada peneltian ini adalah teknik purposive sampling. Purposive sampling merupakan teknik penarikan sampel dengan cara menentukan informaninforman yang mewakili sejumlah informasi yang dibutuhkan oleh peneliti (Ahmadi. 2014: 86) . Jenis data dalam penelitian ini adalah data primer dan data sekunder. Teknik pengumpulan data yang digunakan adalah observasi, wawancara dan studi dokumentasi. Uji keabsahan data dilakukan melalui triangulasi sumber dan data. Sumber dan data yang diperoleh akan dianalisis melalui tahap reduksi data, penyajian data dan penarikan kesimpulan lalu di verifikasi.

\section{HASIL DAN PEMBAHASAN}

Penelitian ini dilakukan
pada masa pandemi Covid-19.
Maka dari itu pihak LPKA
melarang adanya kunjungan yang
melibatkan anak secara langsung
sesuai dengan arahan Satgas
Penanganan Covid-19 nasional.
Selain kendala pandemi Covid-19,
hasil penelitian juga menunjukan
adanya kendala-kendala yang
menghambat jalannya pembinaan
moral di LPKA Kelas IIB Tanjung
Pati sebagaimana dijelaskan
berikut ini.

Tidak tersedianya tenaga ahli dalam bidang pembinaan moral anak

Dari hasil observasi dan wawancara, peneliti menemukan bahwa tidak ada tenaga ahli di bidang psikologi seperti psikolog dan konselor dan tenaga ahli tetap dibidang agama. Pentingnya peran psikolog dalam pembinaan moral anak adalah mampu menjadi wadah dalam mengenalkan pendidikan karakter. Dengan adanya psikolog dapat memberikan gambaran yang baik tentang standar karakter bagi anak. Selain itu, Tenaga ahli dalam bidang agama juga diperlukan. Salah satu hal penting dalam membina moral pada anak adalah adanya pembinaan agama yang dilakukan secara rutin dan periodik. Berdasarkan teori Van Meter dan Van Horn, variabel "sumber daya" merupakan hal yang sangat memengaruhi keberhasilan pelaksanaan suatu kebijakan (Zulfian. 2014: 36) Dalam hal ini sumber daya yang dimaksud adalah Sumber Daya Manusia (SDM). Tujuan dari suatu lembaga akan mudah tercapai apabila SDM di lembaga tersebut memenuhi secara kuantitas dan kualitas.

Pembinaan Moral yang tidak terlaksana imbas pandemi Covid-19

Pembinaan moral di LPKA Kelas II B Tanjung Pati terletak pada pembinaan kepribadian. 
Pembinaan kepribadian tersebut meliputi pembinaan kesadaran beragama, pembinaan kesadaran berbangsa dan bernegara, pembinaan intelektual, dan pembinaan kesadaran hukum. Pembinaan kepribadian tersebut jika dilaksanakan dengan sungguhsungguh maka akan dapat meningkatkan aspek-aspek moral pada anak yaitu moral keagamaan, moral sosial, moral lingkungan dan moral individu (Oktaviana. 2017). 4 aspek tersebut sangat penting dikembangkan apabila ingin menciptakan anak dengan kepribadian yang baik.

Namun, akibat Covid-19 beberapa pembinaan tersebut tidak berjalan. Pembinaan kesadaran intelektual. Berdasarkan hasil observasi dan wawancara pembinaan ini tidak berjalan selama masa pandemi Covid-19. Seluruh kunjungan di di LPKA dihentikan, termasuk kunjungan dari tenaga pendidik. Alhasil, Program paket A, B, dan C tidak berjalan. Anak-anak dibiarkan saja beraktivitas atau bermain di wilayah LPKA selama jam belajar.

Pembinaan kesadaran beragama. Berdasarkan hasil obsrvasi dan wawancara, pembinaan kesadaran beragama yang masih berjalan pada masa pandemi Covid-19 yaitu belajar mengaji dan sholat. Kegiatan ceramah yang biasanya dilakukan 1 atau 2 kali seminggu harus terhenti karena ustadz atau guru tidak boleh berkunjung ke LPKA Kelas II B Tanjung Pati. Sehingga pembinaan kesadaran beragama tidak terlaksana pada masa pandemi.

Van Meter dan Van Horn (Zulfian. 2014) juga mengatakan variabel yang mempengaruhi implementasi suatu kebijakan adalah lingkungan sosial, ekonomi, dan politik. Keadaan yang tidak stabil diakibatkan pandemi Covid19 ini benar-benar menghambat semua kegiatan manusia, termasuk kegiatan pembinaan di LPKA Kelas II B Tanjung Pati.

\section{Kekurangan fasilitas dalam pelaksanaan pembinaan}

Berdasarkan hasil penelitian, peneliti mendapatkan adanya upaya pihak LPKA Kelas II B Tanjung Pati dalam mengatasi kendala di bidang pendidikan anak didik pemasyarakatan. Upaya tersebut adalah mengadakan proses belajar dan mengajar secara virtual. Namun, hal tersebut masih berupa rencana. Berdasarkan pendapat bapak Masri Fabrar, Aks selaku Kasi pembinaan menyatakan LPKA Kelas II B Tanjung Pati masih kekurangan dalam hal komputer bagi anak didik pemasyarakatan. Komputer yang digunakan saat ini dipakai 
secara bergantian untuk berkomunikasi dengan keluarga.

Kemudian menurut Van Meter dan Van Horn (Zulfian. 2014) variabel yang mempengaruhi adalah "sumber daya" yaitu kurangnya fasilitas pada LPKA Kelas II B Tanjung Pati. Variabel lain yang mempengaruhi kebijakan adalah "komunikasi" yaitu kurangnya komunikasi antar organisasi terkait kegiatan-kegiatan yang dilaksanakan. Kemitraan sagat penting dilakukan dalam memenuhi kebutuhan yang tidak dapat dipenuhi sendiri dan dengan bekerjasama dapat memperoleh hasil yang lebih baik (Al Azhar dkk. 2013).

\section{KESIMPULAN}

Berdasarkan temuan penelitian yang dilakukan di LPKA Kelas II B Tanjung Pati dapat disimpulkan bahwa pembinaan moral di LPKA pada masa pandemi Covid-19 belum terlaksana dengan optimal karena banyak kegiatan yang tidak berjalan. Tidak hanya itu, pembinaan moral pada anak didik pemasyarakatan tidak terlaksana dengan baik karena tidak ada psikolog dan konselor serta tenaga ahli yang tetap di bidang agama. Padahal psikolog dan agama berperan penting dalam pembinaan moral anak.

\section{DAFTAR PUSTAKA}

Al Azhar, Muchtar Luthfi Malik, dkk. (2013). Kemitraan antara Pemerintah dan Swasta dalam Pelayanan Publik. Jurnal Administasi Publik (JAP), Vol. 1, No. 5, Hal. 1048-1057.

Eriza, D. (2018). Peranan Petugas Lpka (Lembaga Pembinaan Khusus Anak) Klas Ii Bandar Lampung Dalam Pembinaan Anak Didik Tindak Pidana Kriminal. Universitas Islam Negeri Raden Intan Lampung.

Fitesa, N. (2016). Peran Petugas Lembaga Pembinaan Khusus Anak (Lpka) Kelas Iib Dalam Memberikan Pembinaan Terhadap Anak Didik Pemasyarakatan (Studi di LPKA Kelas IIB Provinsi Sumatera Barat). Universitas Andalas.

Keputusan Menteri Hukum dan Hak Asasi Manusia RI Nomor M.HH-03.OT.02.02. 2014

Nurmalisa, Y., \& Adha, M. M. (2016). Peran Lembaga Sosial Terhadap Pembinaan Moral Remaja Di Sekolah Menengah Atas. Jurnal Ilmiah Pendidikan Pancasila Dan Kewarganegaraan, 1(1), 64-71.

https:/ / doi.org/10.17977/u m017v21i22016p064 
Oktaviana, Shintia. 2017. Pembinaan Moral Terhadap Warga Binaan Di Lembaga Pemasyarakatan Kelas IIB Kota Tegal. Skripsi. Fakultas Ilmu Sosial. Universitas Negeri Semarang.

Sudaryono. 2018. Metodologi Penelitian. Rajawali Pers: Jakarta.

Yuliyanto, \& Ernis, Y. (2016). Lembaga Pembinaan Khusus Anak dalam Perspektif Sistem Peradilan Pidana Anak. Jakarta: Pohon Cahaya.

Zulfian. 2014. Implementasi Kebijakan Program Pendekatan Keluarga Sejahtera dalam pendistribusian alat kontrasepsi di Kabupaten Sintang. Jurnal Administrasi Publik dan Birokrasi. Vol. 1 No. 2. 